\section{THE ALGERO-SPANISH TRIANGULATION}

$\triangle \mathrm{WE}$ have received from Algeria further details as to the execution of the triangulation of the AlgeroSpanish geodetic arc. The stations in the Algerian province of Oran are Msabia, a farm held by a colonist in the Mordzago at an altitude of 585 metres, and Mount Filhaoucen, at an altitude of 1,100 metres in Traras. These stations are at a distance of 108 kilometres from each other. The Spanish engineers have located themselves at Mulhacen, 3,500 metres altitude, in the Sierra Nevada, and Tetica, in the province of Murcia, 2,400 metres altitude. The distance from Tetica to Mulhacen is 88 kilometres. The two lines, Msabia-Tetica and Filhaoucen-Mulhacen, are respectively 270 and 300 kilometres long. In day-time signals were exchanged by sunlight and reflected by silvered glass mirrors 30 centimetres diameter ; at night a Gramme electric machine was used in each station and worked by steam engine. The mirrors used for the electric light are 50 centimetres diameter. A telegraph line has been established from Oran to Msabia, a distance of 16 kilometres, so that Msabia is placed in direct communication with the European system. "The temperature of the Spanish stations was very low, and fell several degrees under zero, while the heat was very great in the Algerian stations, which must be taken into account in the calculation of atmospheric refractions. Colonists and especially Arabs showed much surprise at seeing their mountains illuminated by a powerful ray of light which the French officers were sending from Filhaoucen and Msabia in the interval of operations. They were heard to say that the French had inherited the power of Allah, as they were making suns and stars.

\section{THE IRON AND STEEL INSTITUTE}

$T H E$ annual autumn or country meeting of this Association was held last week at Liverpool, in the concert room of St. George's Hall, the proceedings being opened with a few hearty words of welcome from the Mayor. The report of council showed that the Institution continued to flourish in spite of the hard times in the trade, fifty-eight new members having been added to the list on the last ballot and the proposal papers of thirtyeight received. The President then announced that the Council had accepted an invitation, numerously signed by representative firms in the iron trade of Westphalia to hold the autumn meeting of 1880 at Düsseldorf, which proposal was unanimously confirmed by the meeting.

After the completion of the formal business, the proceedings commenced with a discussion on the very useful method of determining manganese in iron ores, spiegel, ferromanganese, \&c., by the volumetric method described by Mr. Pattinson, of Newcastle, at the last meeting in Londion, and which, according to the generally expressed opinion of chemists present, seems destined, for commercial purposes at any rate, to take the place of the more tedious analytical methods now in use.

Among the new communications prominence was given to a paper by M. A. Pourcel, of Terrenoire, on the causes of dephosphorisation of iron and steel, the principal idea in which was that the amount of phosphorus reduced from phosphates contained in iron ores depends mainly on the temperature and not on the reducing energy of the furnace temperature, instancing the fact that from the same ores pig-iron containing phosphorus in proportions varying from I to 3 might be obtained in the blast-furnace, according as the coke charge in the furnace was heavily burdened or not, a conclusion that did not find much favour among the members present.

A second paper on the neutralisation of phosphorus in iron and steel, by Mr. Richard Brown, of Ayr, proposed the addition of small doses of bichromate of potassium to the metal in the converter or melting furnace in order to introduce a small proportion of chromium into the finished steel. According to the author's statement, metal with from I to I $\frac{1}{2}$ per cent. of phosphorus may be made to show fair working qualities, when containing 0.1 to 0.2 per cent. of chromium as a corrective, but from the results of the tests produced in support it appeared to be extremely irregular, as regards extension under strain. In the discussion on this paper some interesting remarks were made incidentally by $\mathrm{Mr}$. Riley on the working of a chromiferous pig iron, which was made to some extent in Tasmania, and from which great things were expected, but it had been found impracticable to produce clean iron from it in the puddling furnace, owing to the refractory character imparted by the chromium to the slag. Another paper by Mr. Bull reproduced the old idea of dephosphorising by means of steam, but no very new facts appear to have been brought forward by the author. A useful method of compressing the tops of steel ingots by the direct action of high pressure on the surface of the molten metal, invented by Mr. H. R. Jones, of Pittsburg, Pennsylvania, was described by Mr. Davis. This appears to mark a real progress in the manipulation of the metal, as the proportion of unsound ingots is said to be notably reduced by its use. Of more general interest than the formal papers, however, was the statement made by Mr. Windsor Richards, on the progress achieved in the dephosphorising of Cleveland pig-iron in the Bessemer converter by the ThomasGilchrist-Snelus process since the last meeting, which Mr. Bell pronounced to be an absolute scientific success, steel rails produced by this method at Eston from Cleveland ore having satisfactorily passed the tests prescribed by the North-Eastern Railway Company. Several minor papers less intima:ely connected with the main objects of the Institution, such as the use of glass toughened by Siemens's process of annealing for tramway sleepers, the progress of iron and steel as constructive materials were also read during the meeting. The afternoons, in accordance with the usual custom, were devoted to excursions, the members being fortunate enough to have the three finest examples of the Transatlantic steamers belonging to the Cunard, Inman, and White Star Lines in port and available for their inspection at the same time. The Warrington Wire Works, the largest manufactory of the class in the country, the enormous locomotive engine, boiler, and steel works of the London and North Western Railway Company at Crewe, Messrs, MacCorquodale's Railway Printing Office, and several of the large collieries in the Wigan district were also inspected by the members on the remaining afternoon of this very successful meeting.

\section{NOTES}

THe Autumn Congress of the Sanitary Institute will be held at Croydon from the 21 st to the $25^{\text {th }}$ inst, under the presidency of Dr. B. W. Richardson. The exhibition will be opened at 3 P.M., on the 2 rst, and in the evening Dr. Richardson will give his presidential address. On the 22nd Dr. Alfred Carpenter will give the address in the Section of Sanitary Science and Preventive Medicine; on the 23rd Capt. Douglas Galton, in the Section of Engineering and Sanitary Construction; and in the evening Prof. Corfield will give a lecture to the Congress; on the 24 th $\mathrm{Mr}$. G. J. Symons will give the address in the Section of Meteorology and Geology. Saturday, the $25^{\text {th }}$, will be devoted to discussion. The results of the examinations conducted by the Institute having shown the necessity for some systematic plan of technical instruction in sanitary science, the Council have decided to establish a School of Hygiene in London, to be opened during the month of November next. The course of instruction will include the following subjects:-Preventive Medicine. Practical Sanitary Science- $-(a)$ Medical and Chemical; (b) Engineering and Constructive. Jurisprudence and Sanitary Law. The following 